\title{
DETERMINANTS OF STUNTING IN TAMBAKREJA VILLAGE, SOUTH CILACAP DISTRICT, CILACAP
}

\author{
Majestika Septikasari \\ School of Health Al-Irsyad Al-Islamiyyah Cilacap, Central Java, Indonesia \\ majestika86@gmail.com
}

\begin{abstract}
Stunting not only increases the risk of children morbidity and mortality but also decreases intelligence and increases the risk of chronic diseases as adults. This study aims to analyze the influence of MUAC on early pregnancy, birth weight, birth length, EBI, number of under-five children in house and mother education on stunting This is a descriptive correlative research with cross-sectional approach conducted in Tambakreja Village, south Cilacap District, Cilacap in 2018. The number of sample was 79 children from Puspa Kencana integrated health service center. Data analysis was univariate and bivariate analysis with Fisher test. The results showed number of children give strong effect on stunting $(\mathrm{OR}=3.29 ; 95 \% \mathrm{CI}=0.61-17.85 ; \mathrm{p}=0.162)$. MUAC in early pregnancy $(\mathrm{OR}=2.30 ; 95 \% \mathrm{CI}=0.40-13.32 ; \mathrm{p}=0.302)$, birth length $(\mathrm{OR}=2.72 ; 95 \%$ $\mathrm{CI}=0.26-27.99 ; \mathrm{p}=0.388)$ and $\mathrm{EBI}(\mathrm{OR}=1.74 ; 95 \% \mathrm{CI}=0.30-10.12 ; \mathrm{p}=0.426)$ have moderate effect towards the risk of stunting. While birth weight has weak effect to stunting $(\mathrm{OR}=1.09 ; 95 \% \mathrm{CI}=1.02-1.16 ; \mathrm{p}=0.724)$ and mother education has negative effect toward stunting $(\mathrm{OR}=0.96 ; 95 \% \mathrm{CI}=0.164-5.61 ; \mathrm{p}=0.668)$. CED in early pregnancy, LBW, non EBI and short birth length increase the risk of stunting.
\end{abstract}

Keywords: MUAC, birth weight, birth length, breastfeeding initiation, mother education, number of children in house, stunting

\section{BACKGROUND}

One of the nutritional problems of children in Indonesia is the high prevalence of stunting. Stunting is chronic malnutrition condition that seen based on anthropometric indicators of the height of body per age are less than -2 SD. Based on the results of monitoring the nutritional status of the Ministry of Health RI in 2017 as many as $29.6 \%$ 
of children under five in Indonesia have stunting. This figure is higher than the maximum number of stunting stipulated by WHO. According to WHO, stunting rates in a region should not exceed $20 \%$. The incidence of stunting in Central Java is not higher than the national figure of $20.6 \%$. However, stunting in Cilacap, one of the districts in Central Java exceeded the stunting rate of $27.2 \%$ [1]

In the short-term stunting increases the risk of children's morbidity and mortality. Stunting is associated with an increased risk of pneumonia and diarrhea infections. This is because children with stunting have lower immune levels than normal children [2]. Stunting also lead in disruption of child growth and development. Chang et al. (2010) in his research mentioned that children aged 9-24 months with stunting have lower intelligence levels and have weaknesses in hand, eye, hearing, speech and performance coordination than children who do not experience stunting [3]. The results of this study are in line with research conducted by Martorell et al. (2010) where the incidence of stunting in children is associated with the slow motor development and lowlevel of intelligence [4]. In addition to short-term effects, stunting also has a long-term effect of increasing the risk of chronic diseases as adults. Children with rapidly rising stunting will have a higher risk of hypertension and diabetes [5]. In the wider scale, stunting will have an impact on the economy and national development. In low cognitive levels, the risk of chronic disease in adulthood as a result of stunting in childhood will lead to decrease quality of life and productivity. Low levels of work productivity impact on low wages [6]

High stunting rates indicate a long-term or chronic deficiency in children. Stunting begins at the beginning of a conception when a young woman who is malnutrition and anemic, pregnant then becomes a mother. It is worse when the baby is not getting adequate nutrition. Black et al. suggests that malnutrition in pregnant women contributes to about $20 \%$ of maternal deaths, increasing the risk of adverse pregnancy outcomes, child mortality and stunting [7]. Chronic Energy Deficiency (CED) in pregnant women will affect the disruption of growth and development of the fetus that can increase the risk of babies who are born weighing less than 2500 grams or commonly called low birth weight (LBW). A study conducted by Nadiah (2014) showed that LBW infants are 2.2 times more likely to have stunting than infants without LBW [8]. 
Another factor that can increase the risk of stunting is the length of the body at birth. Short-term infants are 1.9 times having stunting risk than babies born with normal body length [9]. Stunting is directly affected by adequate nutrition intake. In the early days of birth, baby only requires breast milk to sufficient the nutritional needs. Pre-lactal feeding may lead to non-fulfillment of infant nutrition that may result in stunting risk. The study conducted by Muchina \& Waithaka (2010) stated children who get pre-lactal food 1.8 times more are at risk of stunting. The number of children in the family and the mother's education also contribute to the stunting. Research conducted by Aryu showed the results of the number of children is more than two four times greater risk of stunting compared with families with children less than two. Mothers with low education 1.5 times are more likely to have stunting children than well-educated mothers [10]. This study aims to analyze the influence of mother's upper arm circumference (MUAC) on early pregnancy, birth weight, birth length, early breastfeeding initiation (EBI), number of underfive children in house and mother education on stunting in Tambakreja village, South Cilacap district, Cilacap

\section{METHOD}

This is a descriptive correlative research with cross-sectional approach conducted in Tambakreja Village, south Cilacap District, Cilacap in 2018. The population of this research is all children under five in Tambakreja Village. The number of sample was 79 children from puspa kencana integrated health service center. The sample determination was based on the consideration of the representation of the population and the region with the most wasting children (15\%) in Tambakreja village. Wasting is an indicator of acute malnutrition while stunting is chronic malnutrition and both are often correlated [1]. The samples were taken from children who were not sick or diarrhea and had Mother Children Health $(\mathrm{MCH})$ books which contained maternal education data, MUAC on early pregnancy, newborn weight and birth length. Data of children nutrition status was compared by the nutritional status table of the Ministry of Health RI divided into two categories, normal if height/age 2 SD to -2 SD and stunting if height/age -2 SD to -3 SD. The children's age was calculated based on the date of birth up to the time of examination. MUAC early pregnancy is divided into two categories normal $\geq 23.5 \mathrm{~cm}$ and $\mathrm{CED}<23.5 \mathrm{~cm}$. Birth weight is divided into normal categories 
2500-4000 gr and BLW <2500 gr. The birth length is divided into normal $>46 \mathrm{~cm}$ and short $<46$. Maternal education is high if the mother has a minimum high school education or equal, and it is low if the maximal education of junior high school or equal. EBI history data and the number of under-five children at home were obtained through questionnaires. Data analysis performed include univariate and bivariate analysis with Fisher test and the size of influence seen by the value of OR. Presentation of data in the form of tables presented by narration

\section{RESULT}

Table 1 Frequency distribution

\begin{tabular}{lcc}
\hline Variabel & $\mathrm{n}$ & $\%$ \\
\hline Independen Variabel & & \\
MUAC & 38 & 48.1 \\
a. CED & 41 & 51.9 \\
b. Normal & & \\
Birth Weight & 4 & 5.1 \\
a. LBW & 75 & 94.9 \\
b. Normal & & \\
Birth Leght & 6 & 7.6 \\
a. Short & 73 & 92.4 \\
b. Normal & & \\
EBI & 43 & 54.4 \\
a. No EBI & 36 & 45.6 \\
b. EBI & & \\
Number of Children in & & \\
House & 20 & 74.7 \\
a. >1 & 59 & 34.2 \\
b. 1 & & 65.8 \\
Mother education & 27 & \\
a. Low & 52 & 7.6 \\
b. High & & 92.4 \\
Dependen Variabel & & \\
Children nutriotion status & 6 & \\
a. Stunting & 73 & \\
b. Normal & & \\
\hline
\end{tabular}

The research result of stunting determinant in Tambakreja village, south Cilacap district, Cilacap can be seen in table 1 . Based on table 1 as many as $7.6 \%$ of sample is stunting. Children who were born from mother with CED in pregnancy and without CED in pregnancy almost balanced that is $48.1 \%$ and $51.9 \%$. Most of the samples were born with $2500-4000$ gr weight $93.7 \%$. There were only $5.1 \%$ of samples have low birth 
weight and $7.6 \%$ have short birth length. As many as $54.4 \%$ of children without EBI shortly after birth. The number of children under five indicates that most of them have only one toddler in the house $(74.7 \%)$ and the majority of mother education is high school or equal $56.8 \%$ ).

Table 2 Bivariate analysis

\begin{tabular}{|c|c|c|c|c|c|c|c|c|}
\hline \multirow{3}{*}{ Independen Variabel } & \multicolumn{4}{|c|}{ Children nutrition status } & \multicolumn{4}{|c|}{$\mathrm{CI}(95 \%)$} \\
\hline & \multicolumn{2}{|c|}{ Stunting } & \multicolumn{2}{|c|}{ Normal } & \multirow[t]{2}{*}{ OR } & \multirow{2}{*}{$\begin{array}{l}\text { Lower } \\
\text { limit }\end{array}$} & \multirow{2}{*}{$\begin{array}{l}\text { Upper } \\
\text { limit }\end{array}$} & \multirow[t]{2}{*}{$\mathrm{p}$} \\
\hline & $\mathrm{n}$ & $\%$ & $\mathrm{n}$ & $\%$ & & & & \\
\hline MUAC & & & & & 2.30 & 0.40 & 13.32 & 0.302 \\
\hline CED & 4 & 5,1 & 34 & 43 & & & & \\
\hline Normal & 2 & 2.5 & 39 & 49.4 & & & & \\
\hline Birth Weight & & & & & 1.09 & 1.02 & 1.16 & 0.724 \\
\hline LBW & 2 & 2.5 & 3 & 3.8 & & & & \\
\hline Normal & 4 & 5.1 & 70 & 88.6 & & & & \\
\hline Birth lenght & & & & & 2.72 & 0.26 & 27.99 & 0.388 \\
\hline Short & 1 & 1.3 & 5 & 6.3 & & & & \\
\hline Normal & 5 & 6.3 & 68 & 86.1 & & & & \\
\hline EBI & & & & & 1.74 & 0.30 & 10.12 & 0.426 \\
\hline No EBI & 4 & 5.1 & 39 & 49.4 & & & & \\
\hline EBI & 2 & 2.5 & 34 & 43 & & & & \\
\hline $\begin{array}{l}\text { Number of Children in } \\
\text { House }\end{array}$ & & & & & 3.29 & 0.61 & 17.85 & 0.162 \\
\hline$>1$ & 3 & 3.8 & 17 & 21.5 & & & & \\
\hline 1 & 3 & 3.8 & 56 & 70.9 & & & & \\
\hline Mother education & & & & & 0.96 & 0.164 & 5.61 & 0.668 \\
\hline Low & 2 & 2.5 & 25 & 31.6 & & & & \\
\hline High & 4 & 5.1 & 48 & 60,8 & & & & \\
\hline
\end{tabular}

Table 2 shows a weak influence between the birth weight $(\mathrm{OR}=1.09 ; 95 \% \mathrm{CI}=$ 1.02-1.16; $\mathrm{p}=0.724$ ) to stunting where children born with LBW were 1.09 times more likely to have stunting than children born without LBW. The maternal education variable $(\mathrm{OR}=0.96 ; 95 \% \mathrm{CI}=0.164-5.61 ; \mathrm{p}=0.668)$ had an adverse (negative) effect on the risk of stunting and the effect was not statistically significant. There was a moderate effect between MUAC in early pregnancy $(\mathrm{OR}=2.30 ; 95 \% \mathrm{CI}=0.40-13.32 ; \mathrm{p}=0.302)$, birth length $(\mathrm{OR}=2.72 ; 95 \% \mathrm{CI}=0.26-27.99 ; \mathrm{p}=0.388)$ and $\mathrm{EBI}(\mathrm{OR}=1.74 ; \mathrm{CI} 95 \%=0.30$ $10.12 ; p=0.426)$ towards the risk of stunting. Mothers who at the early pregnancy experience CED will increase the risk of stunting in children by 2.3 times compared to mothers who are not have CED in early pregnancy. Children who are at birth have a body length $<46 \mathrm{~cm}$ have more risk of stunting 2.7 times than children who are born with normal body length. The risk of stunting a toddler will increase 1.7 times greater in children who do not do EBI shortly after birth. The number of under-five at home has a 
strong influence on the risk of stunting incidence in toddlers $(\mathrm{OR}=3.29$; CI95\% $=0.61$ $17.85 ; \mathrm{p}=0.162)$. Children who live on family with more than one toddler will be 2.3 times more likely to have stunting than children who live on family with only one toddler. Although some variables have moderate and strong effects, but the effect of MUAC in early pregnancy, birth weight, birth length, EBI, the number of under-fives in the family, and mother education on stunting risk are not statistically significant.

\section{DISCUSSION}

The CED in early pregnancy can be known by measurement of MUAC which is less than $23.5 \mathrm{~cm}$. CED in pregnancy will affect the disruption of trasplasenta transport that reduce blood flow to the placenta and the nutritional needs of the fetus cannot be maximum fulfilled resulting in disruption of fetal growth. [12] Mothers with CED will be at risk of delivering LBW infants. Children born with LBW, have a chance of having a nervous system disorder so the growth and development will be slower than children born with normal weight. [7] A study conducted in Kwara State, Nigeria found that stunting opportunities would decrease in mothers with better nutritional status during pregnancy compared to mothers with malnutrition status. [13]

Normally newborns weigh between 2500 - 4000 grams. Babies born more than 4000 grams are called big babies, and it is called LBW if the baby is born less than 2500. LBW infants are more susceptible to infectious diseases. If there are not supported by adequate nutrition then the risk of stunting in the future will be greater. [14] Based on the results of the study of children born LBW show risk 1.09 times greater stunting than children born normal. The results of this study are consistent with studies conducted in DhakaBangladesh where children with a history of LBW will have a greater chance of having stunting than a toddler without a history of low birth weight. [15] The study was similar to the study conducted in Brazil, the history of LBW was significantly associated with under-nutrition, stunting and wasting in infants. [7]

The birth length shows the baby's growth during the womb. Short length infants show less nutritional state due to lack of energy and protein during pregnancy. The results showed that children who have short birth length $<46 \mathrm{~cm}$ will be at risk of stunting 2.7 times greater than toddlers born with normal birth length. The results of this study are in line with research conducted by Meilyasari and Ismawati (2014) and Anugraheni (2012) 
in Pati indicates that the risk of stunting is higher among children under five with short birth length $(<48 \mathrm{~cm})$. [16] The risk of developing growth disorders is greater in children who have growth disorders in the previous stage. So that short birth length children are at higher risk of experiencing short at the next age.

The risk of stunting will increase 1.7 times greater in children who do not EBI shortly after birth. The first hour of a baby's life is the best time for a baby to learn breastfeeding. Skin contact between infants and mothers during this period increases the chances of the baby being able to suckle in the first hours of life and in the long run. [17] Children who do not do EBI will have difficulty experiencing at the time of breastfeeding that causes many parents finally give pre-lactal food. Research conducted by Muchina \& Waithaka (2010) children who received pre-lactal food 1.8 times has more risk of stunting than children who did not get pre-lactal food. [10]

The results showed that there was a negative effect of maternal education on stunting risk. High maternal education cannot mean that mothers have a good knowledge in the fulfillment of child nutrition. This is in accordance with research conducted by $\mathrm{M}$. Septikasari (2016) where in her research showed no significant relationship between maternal education level with child nutrition status.[18] Education on the one hand has a positive impact that the mother increasingly understands the importance of health care. But on the other hand, higher education also affects the changes in social values that can affect healthy lifestyles, including the consumption of unhealthy foods that can increase the risk of stunting in children.

Toddlers who live with families with more than one toddler will be 2.3 times more likely to have stunting than a toddler who living with a family with only one toddler. The number of children in the family affects the availability of family food. The large number of children in families with low economic status leads to the non-fulfillment of children's nutritional needs thus increasing the risk of stunting. [19] The number of children in the family effects the available resources, the number of infants in the family can also increase the risk of transmission of infectious diseases that in the long term can result in stunting. The number of infants more than one in the family causes the mother to have difficulty in dividing the time in parenting 


\section{CONCLUSION}

The results showed moderate effect between MUAC in early pregnancy $(\mathrm{OR}=2.30$; $95 \% \mathrm{CI}=0.40-13.32 ; \mathrm{p}=0.302)$, birth length $(\mathrm{OR}=2.72 ; 95 \% \mathrm{CI}=0.26-27.99 ; \mathrm{p}=$ $0.388)$ and $\mathrm{EBI}(\mathrm{OR}=1.74 ; \mathrm{CI} 95 \%=0.30-10.12 ; \mathrm{p}=0.426)$ towards the risk of stunting. While birth weight has weak effect to stunting $(\mathrm{OR}=1.09 ; 95 \% \mathrm{CI}=1.02-1.16 ; \mathrm{p}=$ $0.724)$ and mother education has negative effect toward stunting $(\mathrm{OR}=0.96 ; 95 \% \mathrm{CI}=$ $0.164-5.61 ; \mathrm{p}=0.668)$.

\section{REFERENCE}

[1] Kementerian Kesehatan, "Hasil Pemantauan Status Gizi (PSG) 2016," Biro Komunikasi dan Pelayanan Masyarakat, 2017.

[2] M. J. ohanne H. Rytter, L. Kolte, A. Briend, H. Friis, and V. B. rix Christensen, "The immune system in children with malnutrition--a systematic review," PloS one, vol. 9, no. 8, p. e105017, 2014.

[3] S. M. Chang, S. P. Walker, S. Grantham-Mcgregor, and C. A. Powell, "Early childhood stunting and later fine motor abilities," Developmental Medicine and Child Neurology, vol. 52, no. 9, pp. 831-836, 2010.

[4] R. Martorell et al., "Weight Gain in the First Two Years of Life Is an Important Predictor of Schooling Outcomes in Pooled Analyses from Five Birth Cohorts from Low- and Middle-Income Countries,” Journal of Nutrition, vol. 140, no. 2, pp. 348-354, 2010.

[5] C. G. Victora et al., "Maternal and child undernutrition: consequences for adult health and human capital," The Lancet, vol. 371, no. 9609. pp. 340-357, 2008.

[6] A. J. Prendergast and J. H. Humphrey, "The stunting syndrome in developing countries," Paediatrics and International Child Health, vol. 34, no. 4, pp. 250-265, 2014.

[7] R. E. Black et al., "Maternal and child undernutrition and overweight in lowincome and middle-income countries.," Lancet, vol. 382, no. 9890, pp. 427-51, 2013.

[8] Nadiyah, D. Briawan, and D. Martianto, "Faktor Risiko Stunting Pada Anak Usia 
0 - 23 Bulan Di Provinsi Bali, Jawa Barat, Dan Nusa Tenggara Timur,’ Jurnal Gizi dan Pangan, vol. 9, no. 2, pp. 125-132, 2014.

[9] L. S. Rahayu and M. Sofyaningsih, "Pengaruh BBLR (Berat Badan Lahir Rendah) dan Pemberian ASI Eksklusif terhadap Perubahan Status Stunting pada Balita di Kota dan Kabupaten Tangerang Provinsi Banten,” Peran Kesehatan Masyarakat dalam Pencapaian MDG's di Indonesia, no. April 2011, pp. 160-169, 2011.

[10] E. Muchina and P. Waithaka, "Relationship between breastfeeding practices and nutritional status of children aged 0-24 months in Nairobi, Kenya.," African Journal of Food, Agriculture, Nutrition and Development, vol. 10, no. 4, pp. 23582378, 2010.

[11] A. Candra, "Hubungan Underlying Factors dengan Kejadian Stunting pada Anak 1-2 Tahun,” Non Publication, pp. 1-12, 2011.

[12] M. Septikasari, "Pengaruh Faktor Biologi Terhadap Gizi Kurang Anak Usia 6-11 Bulan Dikabupaten Cilacap," In Seminar Nasional 2016, "Prevent, Control And Treatment Of Diabetes As Major Health Problem Of Non-Communicable And Lifestyle Deseases," 2016, pp. 61-66.

[13] R. O. Babatunde, F. I. Olagunju, S. B. Fakayode, and F. E. Sola-Ojo, "Prevalence and Determinants of Malnutrition among Under-five Children of Farming Households in Kwara State, Nigeria,” Journal of Agricultural Science, vol. 3, no. 3, 2011.

[14] B. C. Rosha, D. Sisca, K. Putri, I. Yunita, and S. Putri, "Determinan Status Gizi Pendek Anak Balita Dengan Riwayat Berat Badan Lahir Rendah (Bblr) Di Indonesia (Analisis Data Riskesdas 2007-2010),” Jurnal Ekologi Kesehatan, vol. 12, no. 3, pp. 195-205, 2013.

[15] A. Jesmin, S. S. Yamamoto, A. A. Malik, and M. A. Haque, "Prevalence and determinants of chronic malnutrition among preschool children: A cross-sectional study in Dhaka City, Bangladesh," Journal of Health, Population and Nutrition, vol. 29, no. 5, pp. 494-499, 2011.

[16] F. Meilyasari and M. Isnawati, "Faktor risiko kejadian stunting pada balita usia 12 bulan di Desa Purwokerto, Kecamatan Patebon, Kabupaten Kendal,” Journal of Nutrition College, vol. 3, no. 2, pp. 16-25, 2014.

[17] S. Agudelo et al., "The effect of skin-to-skin contact at birth, early versus 
immediate, on the duration of exclusive human lactancy in full-term newborns treated at the Clínica Universidad de La Sabana: Study protocol for a randomized clinical trial," Trials, vol. 17, no. 1, 2016.

[18] M. Septikasari, M. Akhyar, and B. Wiboworini, "Effect of Gestational Biological, Social, Economic Factors on Undernutrition in Infants 6-12 Months in Cilacap," Indonesian Journal of medicine, vol. 1, no. 3, pp. 183-193, 2016.

[19] R. Faradevi, "Difference in Size of Family Spending, Number of Children, Energy and Protein Intake Between Thin and Normal Under-Five-Years-Old Babies," Universitas Diponegoro, 2011. 